\title{
HEAVY METAL ACCUMULATION AND CHEMICAL COMPOSITION OF ESSENTIAL OILS OF SALVIA OFFICINALIS CULTIVATED ON HEAVY METAL CONTAMINATED SOILS
}

\author{
Violina Angelova ${ }^{1}$
}

DOI: https://doi.org/10.31410/ITEMA.2019.45

\begin{abstract}
Comparative research has been conducted to allow us to determine the content of heavy metals and chemical composition of Salvia officinalis L oils, as well as to identify the possibility of Salvia officinalis L. growth on soils contaminated by heavy metals. The experimental plots were situated at different distances of $0.5 \mathrm{~km}$ and $15 \mathrm{~km}$, respectively, from the source of pollution the Non-Ferrous-Metal Works (MFMW) near Plovdiv, Bulgaria. On reaching flowering stage the Salvia officinalis L plants were gathered. The content of heavy metals in different parts of Salvia officinalis L. (roots, stems, leaves and inflorescences) was determined by ICP. The essential oil of the Salvia officinalis L. was obtained by steam distillation in laboratory conditions which was analyzed for heavy metals and its chemical composition was determined.

Salvia officinalis L. is a plant which is tolerant to heavy metals and can be grown on contaminated soils. Favorable is also the fact that heavy metals do not influence the development of the Salvia officinalis $L$. as well as on the quality and quantity of the essential oil. Twenty-nine components were identified in the oil. The main compounds of essential oi were as follows: $\alpha$-thujone (15.927-18.912), camphor (16.839-17.826), trans-thujone (5.379-11.575), 1,8-cineole (6.891-7.625), camphene (6.024-6.514), $\alpha$-humulene (5.395-6.098), borneol (4.591-5.394), (e)- $\beta$-caryophyllene (3.868-4.576), limonene (3.458-4.612), bornyl acetate (1.621-3.194), viridiflorene (2.449-5.633), $\beta$-pinene (2.174-2.223), allo-aromadendrene (2.034-4.777). The compounds in the essential oil that decreased as a result of heavy metals pollution are limonene, bornyl acetate and allo-aromadendrene, while the $\alpha$-thujone, trans-thujone, camphor and viridiflorene significantly increased. Observed increase of the levels of $\alpha$-thujone, trans-thujone, and camphor level in the leaves of sage grown on heavy metals polluted soil indicated an improvement of the essential oil quality. The essential oil of Salvia officinalis L. can be a valuable product for the farmers from the polluted regions.
\end{abstract}

Keywords: Heavy Metals, Contaminated Soils, Essential Oil Composition, Salvia Officinalis

\section{INTRODUCTION}

alvia officinalis (sage, also called garden sage, common sage, or culinary sage) is a perennial, evergreen subshrub of the Lamiaceae family, with woody stems, greyish leaves and blue to purple flowers [1]. It is cultivated in the subtropical countries of Central and Eastern Europe, Turkey, Algeria, Asia, America and Africa, Ukraine, India, Ceylon, Madagascar, Tunisia, Morocco, etc. [2-4]. In Bulgaria it is grown in the southern part of the country. The plant is essential oil-bearing, honey-bearing and anti-erosion plant.

There are over 900 species of salvia. Salvia officinalis, Salvia sclarea and Salvia lavandulifolia are of economic importance, as these three species have the highest content of aromatic substances.

Agricultural University-Plovdiv, 12 Mendeleev street, Plovdiv, Bulgaria 
The essential oil is obtained by steam distillation of fresh or dried leaves and inflorescences of the plant. The sage essential oil can be used in the food and alcohol industries (as aromatic vector in the production of salami, cheese and wine), in the pharmaceutical industry and in the perfumery and cosmetics [5]. S. officinalis L. essential oil has antiseptic, anti-inflammatory, antitumor, antispasmodic and antioxidant effects [6-8]. Its pharmacological properties depend on the chemical composition of the essential oil.

The production of S. officinalis essential oil and its chemical composition have been the subject of much investigation around the world. It has been found that monoterpene and sesquiterpene hydrocarbons and their oxygen derivatives are predominant in the composition of S. officinalis oil [9-11]. The qualitative characteristics of essential oils from different countries are similar, but large quantitative differences in the content of the basic compounds have been found, suggesting that these oils are likely to have different biological activity [6, 12-14]. The composition of the oil depends on various factors, such as genetic origin [15], habitat [15-16], environmental conditions such as temperature, day length, intensity of light [15,17-19], season [15], physiological stage (harvest time) [18], plant parts used for essential oil extraction [15, 20], soil composition [21], etc. The development of S. officinalis also has an effect on the oil composition [22]. It was found that $\alpha$-humulene, viridiflorol and manool are predominant in young leaf oil, while the content of camphor or $\alpha$-thujone is lower. In the older leaf oil, the content of $\alpha$-humulene, viridiflorol and manool declines significantly with the simultaneous increase in camphor and $\alpha$-thujone [23]. Cluster analysis shows that young leaf oil belongs to the $\alpha$-humulene chemotype, whereas old leaf oil originating in Serbia belongs to camphor chemotype, and old leaf oil originating in Croatia belonged to the thujone chemotype [24]. Due to the strong influence of these factors the composition of the essential oil often does not match the profile defined according to ISO 9909 [25], which according to Bruneton [26] is: $\alpha$-thujone (18-43\%), $\beta$-thujone (3- 8,5\%), camphor $(4,5-24.5 \%), 1,8$-cineole $(5.5-13 \%), \alpha$-humulene $(0-12 \%), \alpha$-pinene $(1-6.5 \%)$, camphene $(1.5-7 \%)$, citric $(0.5-3 \%)$, linalool and bornyl acetate (maximum $2.5 \%$ ).

Studies have been conducted to evaluate the content of heavy metals in medicinal and aromatic plants [6, 27-29]. Some aromatic and medicinal plants have been found to be capable of accumulating heavy metals when grown on contaminated soils [30]. The content of essential oil and heavy metals in medicinal plants may be influenced by environmental conditions [31], soil geochemical characteristics and plant habitat $[6,29,32]$. It was found that the content of the essential oil obtained from the fresh plant mass of the sage is not affected by the level of heavy metal soil contamination [33]. Zheljazkov [33] found that peppermint can extract significant quantities of heavy metals from the soil. It was found that the tested varieties of mint can be successfully grown on soils highly polluted with heavy metals (in the region of NFMW - Plovdiv (Non-ferrous metals plant), without contamination of the final product - the essential oil. Despite the reduction in the yield (14\%) due to pollution with heavy metals, mint still remains very profitable crop and can be used as an alternative to food crops. Some medical plants such as mint, St. John's wort, sage, marigold, marshmallow, cumin, garlic, garden sorrel, hemp and others can accumulate large amounts of toxic heavy metals in their tissues. They can also be successfully used in phytoremediation and can replace food crops grown under the same conditions [34].

The purpose of this study is to conduct a comparative study that will allow us to determine the content of heavy metals and chemical composition of Salvia officinalis L oils, as well as to identify the possibility of Salvia officinalis L. growth on soils contaminated by heavy metals. 


\section{MATERIAL AND METHODS}

The experiment was performed on an agricultural field contaminated by $\mathrm{Zn}, \mathrm{Pb}$ and $\mathrm{Cd}$, situated at different distances $(0.5$, and $15.0 \mathrm{~km})$ from the source of pollution, the NFMW (Non-Ferrous-Metal Works) near Plovdiv, Bulgaria.

Characteristics of soils are shown in Table I. The soils were slightly neutral to alkalic with moderate content of organic matter and essential nutrients ( $\mathrm{N}, \mathrm{P}$ and $\mathrm{K}$ ). The pseudo-total content of $\mathrm{Zn}, \mathrm{Pb}$ and $\mathrm{Cd}$ is high and exceeds the maximum permissible concentrations (MPC) in soil 1 (S1) (Table 1).

Table 1: Characterisation of the soils used in the experiment

\begin{tabular}{|l|c|c|c|c|c|c|c|c|c|}
\hline Parameter & $\mathbf{p H}$ & $\begin{array}{c}\text { EC, } \\
\mathbf{d S} / \mathbf{m}\end{array}$ & $\begin{array}{c}\text { Organic } \\
\mathbf{C}, \%\end{array}$ & $\mathbf{N}$ Kjeldal,\% & $\begin{array}{c}\mathbf{P}, \mathbf{m g} / \\
\mathbf{k g}\end{array}$ & $\begin{array}{c}\mathbf{K}, \mathbf{m g} / \\
\mathbf{k g}\end{array}$ & $\begin{array}{c}\mathbf{P b}, \mathbf{m g} / \\
\mathbf{k g}\end{array}$ & $\begin{array}{c}\mathbf{Z n}, \mathbf{m g} / \\
\mathbf{k g}\end{array}$ & $\begin{array}{c}\mathbf{C d}, \mathbf{m g} / \\
\mathbf{k g}\end{array}$ \\
\hline $\begin{array}{l}\text { Soil 1 (S1) } \\
\mathbf{0 . 5} \mathbf{~ k m}\end{array}$ & 7,4 & 0,15 & 2,2 & 0,34 & 625,6 & 6960 & 2509,1 & 2423,9 & 64,3 \\
\hline $\begin{array}{l}\text { Soil 2 (S2) } \\
\mathbf{1 5} \mathbf{~ k m}\end{array}$ & 7,5 & 0,15 & 1,54 & 0,12 & 387,3 & 6780 & 49,4 & 172,7 & 1,0 \\
\hline
\end{tabular}

MPC (pH 6.0-7.4) - Pb -100 mg/kg, Cd-2.0 mg.kg, Zn-320 mg/kg

MPC (pH >7.4) $-\mathrm{Pb}-100 \mathrm{mg} / \mathrm{kg}, \mathrm{Cd}-3.0 \mathrm{mg} / \mathrm{kg}, \mathrm{Zn}-400 \mathrm{mg} / \mathrm{kg}$

The test plant was sage. Sage is grown according to conventional technology. 5 plants of each of the areas were used for the analysis. Upon reaching the stage of flowering, sage was harvested and the content of $\mathrm{Pb}, \mathrm{Zn}$ and $\mathrm{Cd}$ in leaves was determined. The essential oil of the sage was obtained by steam distillation in industrial conditions which was analyzed for heavy metals and its chemical composition was determined.

Pseudo-total content of metals in soils was determined in accordance with ISO 11466[35]. The available (mobile) heavy metals contents were extracted in accordance with ISO 14870 by a solution of DTPA [36]. The contents of heavy metals ( $\mathrm{Pb}, \mathrm{Zn}$ and $\mathrm{Cd}$ ) in the plant material (leaves) and in the essential oils of sage were determined by the method of the microwave mineralization. The quantitative measures were carried out by ICP method (Jobin Yvon Emission - JY 38 S, France). Digestion and analytical efficiency of ICP was validated using a standard reference material of apple leaves (SRM 1515, National Institute of Standards and Technology, NIST).

The chemical composition of the oils in hexane (1:1000) were analyzed on Agilent 7890A Gas Chromatography system equipped with FID detector and Agilent 5975C mass spectrometer.

\section{RESULTS AND DISCUSSION}

The results presented in Tables 1 and 2 show that in the soil samples S1 (taken from the area situated at the distance of $0.5 \mathrm{~km}$ from NFMW), the reported values for $\mathrm{Pb}$ were exceeding MPC approved for Bulgaria and reached to $2509.1 \mathrm{mg} / \mathrm{kg}$. In the area located at a distance of 15 $\mathrm{km}$, the contents of $\mathrm{Pb}$ significantly reduce to $49.4 \mathrm{mg} / \mathrm{kg}$. Similar results were obtained for $\mathrm{Cd}$ and $\mathrm{Zn}$. The results for the mobile forms of the metals extracted by DTPA show that the mobile forms of $\mathrm{Cd}$ in the contaminated soils are the most significant portion of its total content and reached to $57,2 \%$, followed by $\mathrm{Pb}$ with $33,8 \%$ and $\mathrm{Zn}$ with $9,8 \%$.

In uncontaminated soils, again the mobile forms of $\mathrm{Cd}$ are the largest part of its total content, followed by $\mathrm{Pb}$ and $\mathrm{Zn}$. 
Table 2. DTPA - extractable $\mathrm{Pb}, \mathrm{Zn}$ and $\mathrm{Cd}(\mathrm{mg} / \mathrm{kg})$ in soils sampled from NFMW

\begin{tabular}{|c|c|c|c|c|c|c|}
\hline \multirow{2}{*}{ Soils } & \multicolumn{2}{|c|}{ Pb } & \multicolumn{2}{c|}{ Cd } & \multicolumn{2}{c|}{ Zn } \\
\cline { 2 - 7 } & $\mathrm{mg} / \mathrm{kg}$ & $\%^{*}$ & $\mathrm{mg} / \mathrm{kg}$ & $\%$ & $\mathrm{mg} / \mathrm{kg}$ & $\%$ \\
\hline S1 & 849.1 & 33,8 & 36.8 & 57,2 & 236.8 & 9,8 \\
\hline S2 & 21.5 & 43.5 & 0.7 & 70 & 38.9 & 22.5 \\
\hline
\end{tabular}

DTPA - extractable / total content

A significant accumulation of $\mathrm{Pb}$ is found in the leaves of the sage. The content of this element reaches up to $108,1 \mathrm{mg} / \mathrm{kg}$ in leaves of the sage grown at a distance of $0.5 \mathrm{~km}$ from NFMW (Table 3). Probably a portion of heavy metals absorbed by the conduction system moves from the roots to the above-ground parts of the sage and are accumulated predominantly there. Probably a portion of the accumulated heavy metals in the above-ground mass of the sage is also due to aerosol pollution, which can be explained by the anatomical and morphological characteristics of the crop. The greater accumulation of $\mathrm{Pb}$ in the leaves is probably due to the fact that the leaves of sage are covered by many short soft, which favors the attachment of the aerosols and their accumulation therein. The content of $\mathrm{Cd}$ in the leaves of the sage grown at a distance of 0.5 $\mathrm{km}$ from NFMW reaches up to $1.3 \mathrm{mg} / \mathrm{kg}$, values considered to be non-toxic to plants. According to Kabata-Pendias [37] $5.0 \mathrm{mg} / \mathrm{kg} \mathrm{Cd}$ is considered to be a toxic value for the plants. Our results show the low ability of the sage to accumulate $\mathrm{Cd}$ in the above-ground mass.

The content of $\mathrm{Zn}$ in the stems and leaves of the sage grown at a distance of $0.3 \mathrm{~km}$ from NFMW reaches up to $120.4 \mathrm{mg} / \mathrm{kg}$, as these values are also less the critical values for plants $100-400 \mathrm{mg} / \mathrm{kg}$.

With increasing the distance from NFMW a clear trend is seen towards reducing the content of heavy metals in the leaves of the studied crop. Significantly lower is the content of heavy metals in the leaves of the sage grown at $15 \mathrm{~km}$ from NFMW. The content of heavy metals in the leaves of the sage grown at $15 \mathrm{~km}$ from NFMW reaches up to $0.27 \mathrm{mg} / \mathrm{kg} \mathrm{Pb}, 0.02 \mathrm{mg} / \mathrm{kg}$ $\mathrm{Cd}$ and $13.6 \mathrm{mg} / \mathrm{kg} \mathrm{Zn}$.

Table 3. Content of $\mathrm{Pb}, \mathrm{Cd}$ and $\mathrm{Zn}(\mathrm{mg} / \mathrm{kg})$ in leaves and essential oil of sage

\begin{tabular}{|l|c|c|c|c|c|c|}
\cline { 2 - 7 } \multicolumn{1}{c|}{} & \multicolumn{2}{c|}{ Pb } & \multicolumn{2}{c|}{ Cd } & \multicolumn{2}{c|}{ Zn } \\
\cline { 2 - 7 } \multicolumn{1}{c|}{} & leaves & oil & leaves & oil & leaves & oil \\
\hline S1 (0.5 km) & 108,1 & 0,15 & 1,27 & nd & 120,4 & 1,3 \\
\hline S2 (15.0 km) & 0,27 & 0,14 & 0,02 & nd & 13,6 & 0,89 \\
\hline
\end{tabular}

n.d. - non detectable

The heavy metal content in the essential oil from sage was also determined. The results obtained show that the majority of the heavy metals contained in the leaves of the sage do not pass into the oil during the distillation, therefore their content in the oil is much lower. $\mathrm{Pb}$ content in the essential oil of sage reaches up to $0.15 \mathrm{mg} / \mathrm{kg}$, Zn up to $1.3 \mathrm{mg} / \mathrm{kg}$, while the content of $\mathrm{Cd}$ is below the limits of the quantitative measurement of the method used. Significantly lower are the figures in the essential oil of sage grown at a distance of $15 \mathrm{~km}$ from NFMW - 0,14 mg/ $\mathrm{kg} \mathrm{Pb}$ and $0,89 \mathrm{mg} / \mathrm{kg} \mathrm{Zn}$. The results obtained show that the content of heavy metals in the essential oils is much lower compared to the leaves of the sage, and the amounts of $\mathrm{Pb}, \mathrm{Zn}$ and $\mathrm{Cd}$ in the oil of sage are lower than the accepted maximum values and meet the requirements of an environmentally friendly product. Our results are in accordance with the ones established by Zheljazkov et al. [33, 38], which found that the heavy metal content in the essential oils of the lavender, basil and mint is very low and is not affected by the level of soil contamination with heavy metals. 
The results of the chromatographic analysis of essential oils obtained by processing of leaves of sage grown at a different distance from NFMW are presented in Table 4 . The values of the main components of the essential oil of sage are compared with the requirements of ISO 9909 [25] for the sage oil. ISO 9909 [25] for medicinal uses regulates the amounts of the following constituents in the essential oil: $\alpha$-thujone (18.0-43.0\%), camphor (4.5-24.5\%), 1,8- cineole $(5.5-13.0 \%)$, trans-thujone $(3.0-8.5 \%)$, $\alpha$-humulene $(\leq 12.0 \%)$, $\alpha$-pinene $(1.0-6.5 \%)$, camphene $(1.5-7.0 \%)$, limonene $(0.5-3.0 \%)$, bornyl acetate $(\leq 2.5 \%)$ and linalool+linalyl acetate $(\leq 1.0 \%)$.

Table 4. Composition of oil of sage (\%) obtained by processing fresh leaves

\begin{tabular}{|c|c|c|c|c|c|}
\hline \multirow{2}{*}{ № } & \multirow{2}{*}{ Compound } & \multirow{2}{*}{$\mathbf{R I}$} & $\mathrm{S} 1(0.5 \mathrm{~km})$ & $\mathrm{S} 2(15.0 \mathrm{~km})$ & \multirow{2}{*}{ ISO 9909} \\
\hline & & & \multicolumn{2}{|c|}{$\%$ of TIC } & \\
\hline 1 & (Z)-Salvene & 865 & 0,237 & 0,275 & \\
\hline 2 & $\alpha$-Pinene & 939 & 4,308 & 3,414 & $1,0-6.5$ \\
\hline 3 & Camphene & 952 & 6,514 & 6,024 & $1.5-7.0$ \\
\hline 4 & Sabinene & 969 & 0,182 & 0,218 & \\
\hline 5 & $\beta$-Pinene & 979 & 2,223 & 2,174 & \\
\hline 6 & Myrcene & 990 & 0,949 & 1,267 & \\
\hline 7 & $\alpha$-Terpinene & 1018 & 0,167 & 0,215 & \\
\hline 8 & p-Cymene & 1026 & 0,416 & 0,533 & \\
\hline 9 & Limonene & 1029 & 3,458 & 4,612 & $0.5-3.0$ \\
\hline 10 & 1,8-Cineole & 1031 & 7,625 & 6,891 & $5,5-13.0$ \\
\hline 11 & $\gamma$-Terpinene & 1061 & 0,341 & 0,474 & \\
\hline 12 & beta-Linalool & 1097 & 0,394 & 0,308 & $<1$ \\
\hline 13 & cis-Thujone & 1102 & 18,912 & 15,927 & $18-43$ \\
\hline 14 & trans-Thujone & 1112 & 5,379 & 11,575 & $3,0-8,5$ \\
\hline 15 & Camphor & 1143 & 17,826 & 16,839 & $4,5-24,5$ \\
\hline 16 & trans-Pinocamphone & 1160 & 0,568 & 0,623 & \\
\hline 17 & Borneol & 1165 & 5,394 & 4,591 & \\
\hline 18 & Terpinen-4-ol & 1177 & 0,457 & 0,542 & \\
\hline 19 & $\alpha$-Terpineol & 1189 & 0,659 & 0,508 & \\
\hline 20 & Bornyl acetate & 1285 & 1,621 & 3,194 & $<2,5$ \\
\hline 21 & (E)- $\beta$-Caryophyllene & 1419 & 4,576 & 3,868 & \\
\hline 22 & $\alpha$-Humulene & 1454 & 6,098 & 5,396 & $<12,0$ \\
\hline 23 & allo-Aromadendrene & 1461 & 2,034 & 4,777 & \\
\hline 24 & $\gamma$-Muurolene & 1477 & 0,527 & 0,493 & \\
\hline 25 & Viridiflorene & 1493 & 5,633 & 2,449 & \\
\hline 26 & $\gamma$-Cadinene & 1513 & 0,805 & 0,722 & \\
\hline 27 & $\delta$-Cadinene & 1524 & 0,246 & 0,374 & \\
\hline 28 & Ledol & 1565 & 0,173 & 0,116 & \\
\hline 29 & Caryophyllene oxide & 1583 & 0,117 & 0,105 & \\
\hline & Total & & 97,839 & 98,504 & \\
\hline
\end{tabular}

RI - Relative Index; TIC - Total Ion Current

Good quality sage oil must contain a high percentage ( $>50 \%$ ) of epimeric $\alpha$ - and $\beta$-thujones and $<20 \%$ of camphor [4]. A-Thujone is known to be more toxic than $\beta$-thujone, due to many of the biological effects of sage.

The results we obtained show that oxygen-containing monoterpenes (1,8-cineole, $\alpha$-thujone and $\beta$-thujone, camphor, borneol and bornyl acetate) are predominant in oil, but significant differences in their content are observed in oils from contaminated and uncontaminated area. The content of 1.8-cineole ranges from $6.89 \%$ in the uncontaminated soil (S2) to $7.63 \%$ in the contaminated area (S1); $\alpha$-thujone from $15.30 \%$ (S2) to $18.91 \%(\mathrm{~S} 1), \beta$-thujone from $5.38 \%$ (S1) to $11.58 \%(\mathrm{~S} 2)$; 
camphor from $16.84 \%$ (S2) to $17.83 \%$ (S1); borneol from $4.59 \%$ (S2) to (5.39 (S1); and bornyl acetate from $1.62 \%$ (S1) to $3.19 \%$ (S2). Significant amounts of sesquiterpenes were also found in the oil: $\alpha$-humulene, which ranges from $5.40 \%$ (S2) to $6.10 \%$ (S1); viridiflorene from $2.45 \%$ (S2) to 5.63 (S1); (E)- $\beta$-caryophyllene from 3.87 (S2) up to $4.58 \%$ (S1) A negative correlation was found between the ratio of the amount of $\alpha$ - and $\beta$-thujones to the ratio of camphor and borneol in oils, and the higher content of $\alpha$ - and $\beta$-thujones corresponds to a lower content of camphor and borneol. Similar results were obtained from Kustrak et al. [18] and Pitarevic et al. [39], who found an inverse relationship between the ratio of thujones and camphor in most oils.

Higher levels of sesquiterpenes viridiflorene, humulene and $\gamma$-Cadinene are observed in the oils from the contaminated area compared to the oil from the uncontaminated area. Oils from both regions have significant amounts of camphor (16,839\% -17,826\%), as well as high levels of $\alpha$-thujone $(15,297 \%-18,912 \%)$ and $\beta$-thujone $(5,379 \%-11,575 \%)$.

Stancheva et al. [40] found a higher yield of essential oil from sage grown in heavy metal-contaminated soils, which is confirmed by our results. They found that the amounts of $\alpha$-thujone, $\beta$-thujone $\beta$-cariophyllene and viridoflorol decreased as a result of heavy metal contamination, while the amounts of camphor, borneol, 1,8-cineole and bornyl acetate increased. According to Stancheva et al [40], the decrease in the levels of $\alpha$ - and $\beta$-thujones and the increased level of camphor in sage oil grown on heavy metal contaminated soil leads to a deterioration in the quality of the essential oil, which is not confirmed by our results. The oils from contaminated area oil contains more $\alpha$-pinene, camphene, 1,8-cineole, $\beta$-linalool, $\alpha$-thujone, borneol, (e)- $\beta$-caryophyllene, $\alpha$-humulene, viridiflorene, $\gamma$-cadinene, smaller quantities of myrcene, $\alpha$-terpinene, $p$-cymene, limonene, $\gamma$-terpinene, $\beta$-thujone, trans-pinocamphone, bornyl acetate, allo-aromadendrene, $\delta$-cadinene, ledol and identical amounts of $\beta$-pinene, $(Z)$-salvene, $\gamma$-muurolene, caryophyllene oxide. The probable cause of the difference in the results obtained is due to the ways of cultivation of plants - field vs. vessel trials.

The results of most studies $[18,39,41]$ show great variability of components in sage oil. Franz [42] points out that the difference in the composition of the essential oils within a species seems to be the rule rather than the exception; and is influenced by three main factors: (a) individual genetic variability, (b) plant parts and stage of development, and (c) environment. All these factors influence the ways of biosynthesis of the biologically active components in plants and will subsequently affect the ratio between them.

Most studies have found that oxygen containing monoterpenes $(1,8$-cineole, camphor, $\alpha$-thujone, $\beta$-thrujone, borneol and bornyl acetate), in an amount of 54.9 to $74.5 \%$, represent the main part of sage oil. The monoterpene fraction $(1,8$-cineole, camphor, $\alpha$-thujone, $\beta$-thujone, borneol and bornyl acetate) ranged from 0.7 to $23.0 \%$. Of the sesquiterpene fraction (3.4-15.0\%), (E)-B-caryophyllene and $\mathrm{x}$-humulin are in the highest amounts. Oxygen-containing sesquiterpenes (3.8-275. \%) predominate viridiflorol and manool (0.3 and 8.2\%),

Couladis et al. [24] reported that oxygenated monoterpenes (1,8-cineol, $\alpha$ - and ` $\beta$-thujone, camphor, borneol and bornyl acetate) predominate in the oil, their quantities varying widely.

Craft et al. [23] finds that monoterpenoids $\alpha$-thujone (17-27\%), 1,8-cineole (12-27\%) and camphor $(13-21 \%)$ predominate in oil, with smaller amounts of $\beta$-thujone $(3,8-6.0 \%)$, camphene (3.5-5.3\%) and sesquiterpene $\alpha$-humulene (3.1-4.4\%). There are reports that sage oil from Italy, Romania, the Czech Republic, Portugal and Turkey are characterized by a high content of cam- 
phor (22.0 to $31.79 \%$ ) as a major component in the oil [43]. In contrast, oils in other countries such as Italy, Yugoslavia, Bulgaria and Iran are characterized by their large amount of oxygen monoterpenes, with $\alpha$-thujone, 1,8-cineole and camphor as the main compounds known to exhibit antimicrobial, anti-inflammatory and antioxidant properties [44].

Tucker and Maciarello [45] describe five chemotopy groups based on four major components: (1) camphor $>\alpha$-thujone $>1,8$-cineole $>\beta$-thujone; (2) camphor $>\alpha$-thujone $>\beta$-thujone $>1,8$-cineole; (3) $\beta$-thujone $>$ camphor $>1,8$-cineole $>\alpha$-thujone; (4) 1,8-cineole $>$ camphor $>\alpha$-thujone $>$ $\beta$-thujone; and (5) $\alpha$-thujone $>$ camphor $>\beta$-thujone $>1,8$-cineole.

Jug-Dujakovic et al. [46] based on data from eight major components ( $\alpha$-thujone, camphor, $\beta$-thujone, 1,8-cineole, $\beta$-pinene, camphene, borneol and bornyl acetate) distinguish three Dalmatian sage chemo types from Dalmatia: (A) $\alpha$-1 thujone , 8 -cineole $>\beta$-thujone; (B) $\beta$-thujone $>\alpha$-thujone $>$ camphor $\approx 1,8$-cineole; and $(\mathrm{C})$ camphor $>\alpha$-thujone $>1,8$-cineole $>$ camphene $\approx$ borneol.

Our results show that sage oil from the uncontaminated area belongs to camphor-chemotype camphor (16.84) $>\alpha$-thujone (15.93) $>\beta$-thujone (11.58) $>1,8$-cineole (6.89), whereas the oil from the contaminated area belongs to the thujone-chemotype ( $\alpha$-thujone (18.91)> camphor (17.83)> 1,8-cineole (7.63) $>\beta$-thujone (5.38). The results obtained by us confirm that each sage plant has a unique chemical composition and individual chemotype of the oil.

The chromatographic profile shows a complex mixture of components contained in sage oil. Figure 1 shows the classification of the identified compounds based on functional groups. The highest is the content of oxygen-containing monoterpenes (60-62), followed by monoterpenic hydrocarbons (19\%), sesquiterpene hydrocarbons (13-18\%) and oxygen-containing monoterpenes (3-6\%).
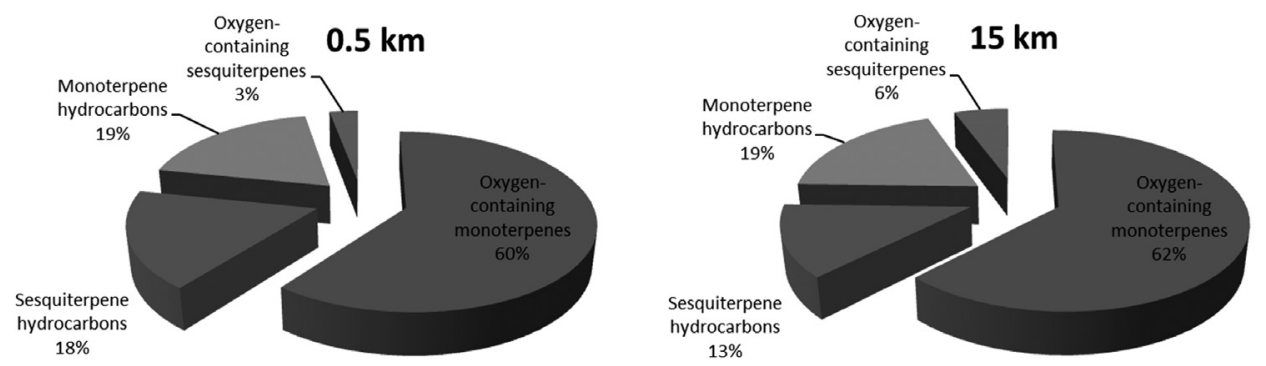

Figure 1: Classification of the identified compounds based on functional groups

Similar results were obtained by Damyanova et al. [41] for oil originating in Bulgaria (oxygen-containing monoterpenes (59.15\%), sesquiterpene hydrocarbons (24.37\%) and monoterpenic hydrocarbons $(14.66 \%)$. The results are in line with those of Santos-Gomes and Fernandes-Ferreira [20] and Farhat et al. [48], who find that oxygen-containing monoterpenes are essential components in sage oil.

The observed differences in the profile of the essential oils of sage when grown on contaminated and uncontaminated soils may be due to the conditions of cultivation of the plants are related to soil contamination.

The main components contained in sage oil grown on contaminated soil are within the standard except limonene, which slightly exceeds the corresponding value in the standard. The content of trans-thujon and limonene from uncontaminated soil oil exceeds the specified values in ISO 
9909, while the content of $\alpha$-thujon is below the values in ISO 9909. The content of all other oil ingredients in our study was within their respective values of the ISO standard.

The composition of the oil from the contaminated area complies with the requirements of 9909 for the use of S. officinalis oil for medical purposes.

\section{CONCLUSION}

Based on the results obtained the following conclusions can be made:

1. Salvia officinalis L. is a plant which is tolerant to heavy metals and can be grown on contaminated soils.

2. The amounts of $\mathrm{Pb}, \mathrm{Zn}$ and $\mathrm{Cd}$ in the oil of sage grown on contaminated soil $(\mathrm{Pb}-2509.1$ $\mathrm{mg} / \mathrm{kg}, \mathrm{Zn}-2423.9 \mathrm{mg} . \mathrm{kg}, \mathrm{Cd}-64.3 \mathrm{mg} / \mathrm{kg}$ ) are lower than the accepted maximum values and meet the requirements of an environmentally friendly product

3. The highest is the content of oxygen-containing monoterpenes in essential oils of sage (60-62), followed by monoterpenic hydrocarbons (19\%), sesquiterpene hydrocarbons (13-18\%) and oxygen-containing monoterpenes (3-6\%).

4. The main components contained in sage oil grown on contaminated soil are within the standard except limonene, which slightly exceeds the corresponding value in ISO 9909.

5. The content of trans-thujon and limonene from sage oil from uncontaminated soil exceeds the specified values in ISO 9909, while the content of $\alpha$-thujon is below the values in ISO 9909.

6. The composition of the oil from the contaminated area complies with the requirements of 9909 for the use of S. officinalis oil for medical purposes.

\section{ACKNOWLEDGEMENT}

The financial support by the Bulgarian National Science Fund Project DFNI H04/9 is greatly appreciated.

\section{REFERENCES}

[1] Pederson, J.A., (2000) Distribution and taxonomic implications of some phenolics in the family Lamiaceae determined by ESR Spectroscopy, Biochemical Systematic and Ecology, vol. 28, pp. 229-253.

[2] Georgiev, E., Stoyanova, A. (2006) A guide for the specialist in aromatic industry. Plovdiv, Bulgaria

[3] Mirijalili. M., Salehi, P., Sonboli, A., Vala, M. (2006) Essential oil variation of Salvia officinalis aerial parts during its phenological cycle, Chem Nat Compd., vol.42(1), pp.19-23.

[4] Raal, A., Orav, A., Arak, E. (2007) Composition of the essential oil of Salvia officinalis L., from varios European countres. Nat Prod Res., vol. 21(5), pp.406-411.

[5] Stojanov, N. (1973) Our medicinal plants. Nauka I izkustvo Press, Sofia, Bulgaria.

[6] Abu-Darwish. M., Cabral, C., Ferreira. I., Gonçalves, M., Cavaleiro, C., Cruz, M., Al-Bdour, T., Salgueiro, I. (2013) Essential oil of Common Sage (Salvia officinalis L.) from Jordan: assessment of safety in mammalian cells and its antifungal and Anti-inflammatory potential, Bio Med Res Int, Article ID 538940:1-9

[7] Fu, Z., Wang, H., Hu, X., Sun, Z., Han, C. (2013) The Pharmacological properties of Salvia essential Oil, J Appl Pharm Sci., vol. 3(7), pp. 122-127. 
[8] Loizzo, R., Tundis, R., Menichini, F., Saab, M., Statti, A., Menichini, F. (2007) Cytotoxic activity of essential oils from Labiatae and Lauraceae families against in vitro human tumor models, Anticancer Res., vol.27, pp.3293-3300.

[9] Fellah, S., Diouf, P.N., Petrissans, M., Perrin, D., Romdhane, M., Abderrabba, M. (2006) Chemical composition and antioxidant properties of Salvia officinalis L. oil from two culture sites in Tunisia, Journal of Essential Oil Research, vol.18(5), pp. 553-556.

[10] Tsankova, E.T., Konaktchiev, A.N., Genova, E.M. (1994) Constituents of essential oils from three Salvia species, Journal of Essential Oil Research, vol.6, pp.375-378.

[11] Velickovic, D., Ristic, M., Randjelovlc, N., Smelcerovic, A. (2002) Chemical composition and antimicrobial characteristicsof the essential oils obtained from flower, leaf and stem of Salvia officinalis L. originated from southern Serbia. Journal of Essential Oil Research, vol.14, pp. 453-458.

[12] Djeddi, S., Bouchenak, N., Settar, I., Halli, L. (2012) Screening of chemical composition and antimicrobial potential of Algerian sage essential oil, Glob J Med Plant Res., vol.1(1), pp.46-49.

[13] Lakhal, H., Ghorab, H., Chibani, S., Kabauche, A., Semra, Z., Smati, Z., Smati, F., Abuhamdah, S., Kabouche, Z. (2013) Chemical composition and biological activities of the essential oil of Salvia officinalis from Batna (Algeria), Scholars Res Libr., vol.5(3), pp. 310-314.

[14] Orhan, I., Özçelik, B., Kartal, M., Kan, Y. (2012) Antimicrobial and antiviral effects of essential oils from selected Umbeliferae and Labiatae plants and individual essential oil components, Turk J Biol., vol.36, pp.239-246.

[15] Perry, N. B., Anderson, R. E., Brennan, N. J. (1999) Essential oils from Dalmatian sage (Salvia officinalis L.): variations among individuals, plant parts, seasons, and sites, J.Agric. Food Chemist., vol.47(5), pp. 2048-2054.

[16] Berotiene, G., Nivinskiene, O., Butkiene, R., Mockute, D. (2007) Essential oil composition variability in sage (Salvia officinalis L.), Chemija, vol.18, pp. 38-43.

[17] Máthé, J. I., Oláh, L., Máthé, A., Miklossy, V., Bernáth, J., Blunden, G., Patel, A., Máthé, I. (1992) Changes in the essential oil production of Salvia officinalis under climatic conditions of the temperate belt. Plant med., vol.58, pp. 680-686.

[18] Kuštrak, D., Kuftinec, J., Blazevic, N. (1984) Yields and composition of sage oils from different regions of the Yugoslavian Adriatic Coast, J Nat Prod., vol. 47, pp. 520-524.

[19] Hadri, A., Gomez del Rio, M., Sanz, J., Coloma, A., Idaomar, M., Ozanas, B. (2010) Cytotoxic activity of $\alpha$-humulene and transcario-phyllene from Salvia officinalis in animal and human tumor cells, An R Acad Nac Farm., vol.76, pp.343-356.

[20] Santos-Gomes, P. C., Fernandes-Ferreira, M. (2001) Organ and seasoned-pendent variation in the essential oil composition of Salvia officinalis L. cultivated in two different sites, J Agric Food Chem., vol.49, pp. 2908-2916.

[21] Piccaglia, R, Marotti, M., Galletti, G. C. (1989) Effect of Mineral Fertilizers on the Composition of Salvia officinalis Oil, Journal of Essential Oil Research, vol.1, pp. 73-83.

[22] Lakušić, B.S., Ristić, M.S., Slavkovska, V.N., Stojanović, D.L.J., Lakušić, D.V. (2013) Variations in essential oil yields and compositions of Salvia officinalis (Lamiaceae) at different developmental stages, Bot. Serb., vol.37, pp.127-139.

[23] Craft, J. D., Satyal, P., Setzer, W. N. (2017) The Chemotaxonomy of Common Sage (Salvia officinalis) Based on the Volatile Constituents, Medicines, vol. 4, pp. 47, doi:10.3390/medicines4030047

[24] Couladis, M., Tzakou, O., Mimica-Dukic, N., Jancic, R., Stojanovic, D. (2002) Essential oil of Salvia officinalis L. from Serbia and Montenegro, Flavour Fragr. J., vol. 17, pp. 119-126.

[25] ISO 9909 (1997), Oil of Dalmatian sage (Salvia officinalis L.).

[26] Bruneton, J. (1999) Pharmacognosy, Phytochemistry Medicinal Plants. Lavoisier Intercept, London, UK 
[27] Amr, S., Đorđević, S. (2000) The investigation of the quality of Sage (Salvia officinalis) originating from Jordan, FACTA Universitatis Series: Working Living Environmental Protection, vol.5, pp.103-108.

[28] Angelova, V., Ivanov, K., Ivanov, R. (2005) Heavy metal content in plants from family Lamiaceae cultivated in an industrially polluted region, Journal of Herbs, Spices and Medicinal Plants, vol.11, pp.37-46.

[29] Blagojević, N., Damjanović-Vratnica, B., Vukašinović-Pešić, V., Đurović, D. (2009) Heavy Metals Content in Leaves and Extracts of Wild-Growing Salvia Officinalis from Montenegro, The Polish Journal of Environmental Studies, vol.18(2), pp. 167-173.

[30] Angelova, V. (2012) Potential of some medicinal and aromatic plants for phytoremediation of soils contaminated with heavy metals, Agrarni Nauki, vol. 4(11), pp. 61-66.

[31] Maksimovic, M., Vidic, D., Milos, M., Molic, M. E. S., Zic, S. A., Siljak-Yakovlev, S. (2007) Effect of the environmental conditions on essential oil profile in two Dinaric Salvia species: $S$. brachyodon Vandas and S. officinalis L., Biochemical Systematic and Ecology, vol.35, pp.473478.

[32] Chan, K. (2003) Some aspects of toxic contaminants in herbal medicines, Chemosphere, vol. 52, pp.1361-1371.

[33] V. D. Zheljazkov, Nielsen, N.E., (1966) Studies on the effect of heavy metals ( $C d, P b, C u, M n$, $\mathrm{Zn}$ and $\mathrm{Fe}$ ) upon the growth, productivity and quality of lavander (Lavandula angustifolia Mill) production, J. Essential Oil Res., vol.8 (3), pp. 259-274.

[34] Bağdat, R. B., Eid, E. M. (2007) Phytoremedation behaviour of some medicinal and aromatic plants to various pollutants, Journal of Field Crops Central Research Institute, vol.16(1-2), pp. $1-10$.

[35] ISO 11466. (1995) Soil quality - Extraction of trace elements soluble in aqua regia.

[36] ISO 14780. (2001) Soil Quality- Extraction of Trace Elements by Buffered DTPA Solution.

[37] Kabata-Pendias, A. (2001) Trace Elements in Soils and Plants, 3rd ed. CRC Press LLC, Boca Raton.

[38] Zheljazkov, V. D., Craker, L.E., Baoshan, X. (2006) Effects of $\mathrm{Cd}, \mathrm{Pb}$ and $\mathrm{Cu}$ on growth and essential oil contents in dill pepper mint, and basil, Environ. Exp. Bot., vol. 58, pp.9-16.

[39] Pitarević, I., Kuftinec, J., Blažević, N., Kuštrak, D. (1984) Seasonal variation of essential oil yield and composition of Dalmatian sage, Salvia officinalis, J Nat Prod., vol.47, pp.409-412.

[40] Stancheva, M., Geneva, M., Hristozkova, M., Boychinova, M., Markovska, Y. (2009) Essential oil variation of Salvia officinalis (L.), grown on heavy metals polluted soil, Biotechnol. and Biotechnol. Eq., vol. 23, pp. 373-376.

[41] Damyanova S., Mollova S., Stoyanova, A., Gubenia, O. (2016) Chemical composition of Salvia officinalis L. essential oil from Bulgaria, Ukrainian Food Journal, vol. (4), pp.695-700.

[42] Franz, C. (1993) Genetics. On: Hay RKM \& Waterman PG (eds.), Volatile Oil Crops: Their Biology, Biochemistry and Production, pp. 63-96, Longman: Harlow, UK.

[43] Dob, T., Berramdane, T., Dahmane, D., Benabdelkader, T., Chelghoum C. (2007) Chemical composition of the essential oil of Salvia officinalis from Algeria. Chem. Nat. Compd., vol.43, pp.491-494.

[44] Radulescu, V., Chiliment, S., Oprea E. (2004) Capillary gas chromatography-mass spectrometry of volatile and semi volatile compounds of Salvia officinalis, J. Chromatogr. A., vol.1027, pp. 121-126.

[45] Tucker, A.O., Maciarello, M.J. (1990) Essential oils of cultivars of Dalmatian sage (Salvia officinalis L.). J. Essent. Oil Res., vol.2(3), pp. 139-144.

[46] Jug-Dujakovic, M., Ristic, M., Pljevljakušic, D., Dajic-Stevanovic, Z., Liber, Z., Hancevic, K., Radic, T., Šatovic, Z. (2012) High diversity of indigenous populations of Dalmatian sage (Salvia officinalis L.) in essential-oil composition. Chem. Biodivers., vol. 9, pp. 2309-2323. 